\title{
Paparan Ultraviolet C Meningkatkan Diameter Pulpa Alba Limpa dan Indeks Mitotik Epidermis Kulit Mencit
}

\section{Ultraviolet C Exposure Increases the White Pulp Diameter of Spleen and Epidermal Mitotic Index of Mice Skin}

\author{
SN Makiyah ${ }^{1}$, Rainy Iszamriach ${ }^{2}$, Arie Nofariyandi ${ }^{2}$ \\ ${ }^{1}$ Bagian Histologi Fakultas Kedokteran dan Ilmu Kesehatan Universitas Muhammadiyah Yogyakarta \\ ${ }^{2}$ Program Studi Pendidikan Dokter Fakultas Kedokteran dan IImu Kesehatan Universitas Muhammadiyah Yogyakarta
}

\begin{abstract}
ABSTRAK
Penelitian ini bertujuan untuk membuktikan efek radiasi sinar ultraviolet C terhadap diameter pulpa alba limpa dan indeks mitotik epidermis kulit mencit. Penelitian eksperimental pada mencit Balb/C, 25 ekor, dibagi menjadi 5 kelompok yaitu kontrol dan empat kelompok perlakuan dengan pemaparan sinar ultraviolet intensitas 15 (P1), 30 (P2), 60 (P3) dan 120 menit (P4) 2 kali sehari selama 15 hari berturut-turut. Sebelum perlakuan, kulit punggung mencit dicukur. Pada hari ke-16, mencit dikorbankan, diambil organ limpa dan kulit punggungnya untuk dibuat preparat histologi. Data berupa diameter pulpa alba limpa dan indeks mitotik dianalisis dengan ANOVA dilanjutkan dengan uji Tukey. Hasil pengukuran diameter pulpa alba limpa pada yang terkecil pada kelompok kontrol yaitu $380,24 \pm 61,91$ diikuti kelompok $\mathrm{P} 1=437,92 \pm 95,59$ selanjutnya kelompok P2=480,48 $\pm 167,55$ dan kelompok P3=492,80 $\pm 138,59$ dan yang terbesar pada kelompok $\mathrm{P} 4=586,00 \pm 41,77$. Hasil pengukuran indeks mitotik epidermis kulit mencit yang terkecil pada kelompok kontrol 9,70 $\pm 2,27$ diikuti kelompok $\mathrm{P} 1=12,2 \pm 1,93$ selanjutnya kelompok $\mathrm{P} 2=13,64 \pm 1,35$ dan kelompok $\mathrm{P} 3=27,48 \pm 3,65$ dan yang terbesar pada kelompok $P 4=38,2 \pm 3,90$. Ada perbedaan bermakna diameter pulpa alba limpa $(p<0,00)$ dan indeks mitotik epidermis kulit mencit $(p<0,00)$. Disimpulkan bahwa paparan sinar ultraviolet $\mathrm{C}$ meningkatkan diameter pulpa alba limpa dan indeks mitotik epidermis kulit mencit.
\end{abstract}

Kata Kunci: Indeks mitotik, mencit, pulpa alba limpa, ultraviolet C

\begin{abstract}
This study aims to investigate the effects of ultraviolet Cexposure on the white pulp diameter of spleen and epidermal skin mitotic index of mice. An experimental study was performed in 5 groups, control and four treatment groups with exposure to ultraviolet $C$ in four different exposure time 15 (P1), 30 (P2), 60 (P3) and 120 minutes (P4) 2 times a day for 15 consecutive days. Before treatment, the mice back skin were shaved. On $16^{\text {th }}$ day, mice were sacrificed, the back skin and spleen were prepared for histology slides to measure white pulp diameter of spleen and mitotic index skin epidermal of mice. The result show that the lowest white pulp diameter of spleen was found in control group 380,24 61,91 and the highest is the P4 group $=586,00 \pm 41,77$. The lowest epidermal skin mitotic index was found in control group $=9,70 \pm 2,27$ and the highest is $P 4$ group $=38,2 \pm 3,90$. A one way ANOVA identify spleen white pulp diameter significant differences between groups $(p<0,00)$ and epidermal skin mitotic index $(p<0,00)$. It can be concluded that ultraviolet $C$ exposure increases spleen white pulp diameter and epidermall skin mitotic index.
\end{abstract}

Keywords: Mitotic index, mice, ultraviolet $C$, white pulp of spleen

Jurnal Kedokteran Brawijaya, Vol. 28, No. 1, Februari 2014; Korespondensi: SN Nurul Makiyah. Bagian Histologi Fakultas Kedokteran dan IImu Kesehatan Universitas Muhammadiyah Yogyakarta, Jl. Lingkar Selatan, Tamantirto, Kasihan, Bantul, DIY 55183 Tel. (0274) 387656Email:nurul_makiyah@umy.ac.id 


\section{PENDAHULUAN}

Paparan sinar matahari dapat memberikan ancaman tidak langsung terhadap kesehatan. Hal ini disebabkan lapisan ozon di stratosphere yang berfungsi untuk menyaring (memfilter) radiasi ultraviolet (UV) dari tahun ke tahun semakin menipis akibat polusi kimia chlorofluoro carbon (CFC) yang berasal dari mesin pendingin (AC, kulkas) dan industri. Menipisnya lapisan ozon, akan mengakibatkan radiasi ultraviolet yang sampai di bumi semakin tinggi intensitasnya (1).

Sinar matahari yang sampai di permukaan bumi dan mempunyai dampak dibedakan menjadi sinar ultraviolet A atau UVA ( $\lambda$ 320-400 nm), sinar UVB ( $\lambda$ 280-320 nm) dan sinar UV C ( $\lambda$ 100-280 nm) (2). Radiasi UVB adalah jenis radiasi dengan keaktifan biologis tertinggi pada sinar matahari dan penyebab reaksi eritema setelah pajanan dengan matahari, sedangkan radiasi UVA mempunyai efek biologis yang lebih rendah daripada UVB dan UV C. Radiasi UV C tidak ditemukan dalam spektrum sinar matahari pada permukaan bumi karena disaring oleh ozon dan air (3).

Fenomena global warming yang berdampak pada penipisan lapisan ozon di bumi dapat menyebabkan radiasi UV C sampai ke permukaan bumi dan berakibat buruk terhadap makhluk hidup (4). Sinar UV C adalah sinar dengan energi tertinggi, paling berbahaya diantara sinar ultraviolet lainnya. Pada manusia, pemaparan sinar UV yang berkepanjangan dapat mengakibatkan gangguan kesehatan secara akut dan kronik pada kulit, mata, otak, sistem imun dan organ lainnya (5).

Sistem imun atau kekebalan terdiri atas organ limfoid dan sel-sel yang tersebar diseluruh tubuh dengan fungsi utama melindungi tubuh terhadap serangan dan perusakan oleh mikroorganisme dan benda asing. Jika sistem imun melemah, kemampuan untuk melindungi tubuh juga akan berkurang sehingga orang lebih mudah terserang penyakit. Salah satu organ limfoid yang berperan dalam sistem imun adalah limpa. Limpa adalah komponen sistem limfoid perifer yang berfungsi menghasilkan limfosit, destruksi eritrosit, pertahanan tubuh terhadap mikroorganisme yang memasuki aliran darah dan sebagai tempat penampungan darah. Pada stuktur limpa terdapat dua jenis pulpa yaitu pulpa alba (putih) dan pulpa rubra (merah). Pulpa alba menghasilkan limfosit yang bermigrasi ke pulpa rubra dan mencapai lumen sinusoid, tempat limfosit tersebut masuk ke dalam darah (6).

Peningkatan aktivitas dari sistem imun pada limpa, dapat diketahui dari ukuran diameter pulpa alba limpa. Diameter pulpa alba limpa yang lebih besar menunjukkan peningkatan aktivitas sistem imun pada limpa. Berdasarkan hasil penelitian Zaidah disebutkan bahwa ada pengaruh yang signifikan peningkatan diameter pulpa alba limpa mencit setelah pemaparan sinar ultraviolet (7).

Ultraviolet $C$ dapat menyebabkan kerusakan kulit dan ultraviolet $C$ paling aktif diabsorbsi oleh DNA (8). Indeks mitotik adalah angka yang menunjukkan aktivitas proliferasi sel terutama pada sel-sel epidermis kulit yang terpapar secara langsung oleh sinar matahari. Indeks mitotik meningkat pada sel-sel epidermis yang terpapar radiasi matahari dengan frekuensi dan intensitas yang lebih banyak. Penelitian ini bertujuan untuk membuktikan efek radiasi sinar ultraviolet dengan mengamati parameter diameter pulpa alba limpa dan indeks mitotik pada epidermis kulit mencit.

\section{METODE}

Jenis penelitian adalah studi eksperimental laboratorium in vivo pada hewan uji mencit. Rancangan penelitian yang digunakan adalah post-test only control group design. Penelitian ini telah mendapatkan persetujuan ethical clearance dari Komisi Etik Penelitian Fakultas Kedokteran dan Ilmu Kesehatan Universitas Muhammadiyah Yogyakarta. Variabel bebas dalam penelitian ini adalah radiasi sinar ultraviolet (UV) C, variabel tergantung adalah diameter pulpa alba limpa mencit dan indeks mitotik pada epidermis kulit mencit. Variabel luar yang dikendalikan adalah umur mencit yang sama, berat badan mencit ratarata sama, faktor genetik dengan menggunakan mencit galur sama yaitu Balb/C dan jenis kelamin betina, faktor lingkungan tempat pemeliharaan mencit yang sama dan waktu pengambilan sampel pada saat yang sama diantara kelompok hewan uji.

Intervensi radiasi sinar ultraviolet dilakukan menggunakan lampu ultraviolet merek Chiyoda Seiki 15 watt, range 280$320 \mathrm{~nm}$, peak $312 \mathrm{~nm}$ (medium wave) dalam dark room dari box alumunium ukuran $60 \times 40 \times 30 \mathrm{~cm}$. Hewan uji yang digunakan adalah mencit galur Balb/C, betina, berjumlah 25 ekor, umur 2 bulan dan berat badan 20-30g.

Mencit dibagi menjadi 5 kelompok yaitu kontrol tanpa perlakuan dan empat kelompok perlakuan dengan pemaparan sinar ultraviolet $C$ intensitas 15 menit (P1), 30 menit (P2), 60 menit (P3) dan 120 menit (P4) 2 kali sehari pagi dan sore selama 15 hari berturut-turut. Paparan sinar ultraviolet dengan lampu ultraviolet $\mathrm{C}$ merek Chiyoda Seiki 15 watt dalam kotak lampu UV. Sebelum perlakuan, mencit dicukur kulit punggungnya seluas $\pm 2 \times 2 \mathrm{~cm}$. Pada hari ke-16, mencit dikorbankan, diambil organ limpa dan kulit punggungnya untuk dibuat preparat histologi. Preparat histologi dibuat di laboratorium Histologi FKH UGM dengan metode parafin dan teknik pewarnaan Hematoksilin Eosin (HE). Preparat limpa diamati secara umum dan diukur diameter pulpa putih dengan mikrometer diletakkan di lensa okuler dengan perbesaran 10x10, hasilnya dikalikan 14x untuk satuan mikron.

Pada preparat kulit punggung mencit, diamati sel-sel pada stratum basale epidermis. Pengukuran indeks mitotik epidermis mencit dilakukan dengan cara menghitung aktivitas mitosis sel epidermis kulit mencit dari $100 \mathrm{sel}$ epidermis mencit. Sel yang sedang dalam fase mitosis memiliki ciri yaitu inti membesar dibandingkan dengan ukuran inti sel normal sekitarnya, kromosom tersebar pada bagian inti (profase), kromosom di bidang tengah (metafase), kromosom di ujung (masing-masing kutub) (anafase), atau terbentuk 2 inti baru dengan ukuran lebih kecil daripada inti sel normal sekitarnya (telofase).

Data yang diperoleh adalah diameter pulpa alba limpa dan indeks mitotik epidermis kulit mencit mempunyai tingkat pengukuran interval dengan 5 kelompok sehingga dianalisis statistik dengan one way ANOVA dan dilanjutkan dengan uji Tukey untuk mengetahui letak perbedaan antar kelompok (9).

\section{HASIL}

Penelitian ini bertujuan untuk membuktikan efek radiasi sinar UV C terhadap sistem imun dengan mengukur diameter pulpa alba organ limpa dan indeks mitotik epidermis kulit mencit. Radiasi sinar UV C dipilih sebagai intervensi karena sinar UV C adalah sinar dengan energi 
tertinggi, paling berbahaya diantara sinar ultraviolet lainnya.

Gambaran histologi limpa setelah pemaparan sinar UV C diamati dengan mengukur diameter pulpa alba limpa seperti terlihat pada Gambar 1.

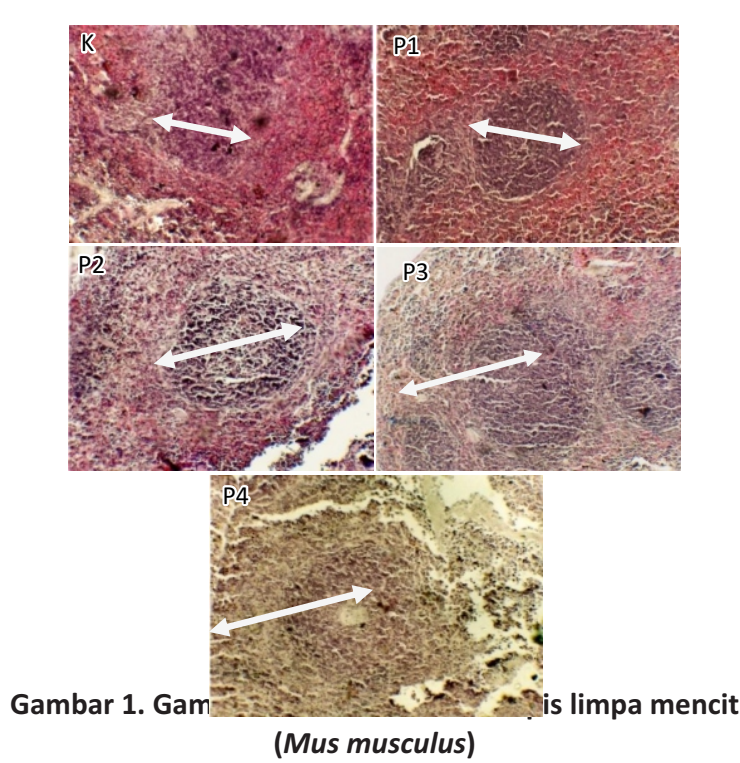

Keterangan:

$\uparrow$ : Diameter pulpa alba limpa yang diukur

K: Kelompok Kontrol

P1: Kelompok pemaparan radiasi sinar UV C selama 15 menit $\mathrm{P} 2$ : Kelompok pemaparan radiasi sinar UV C selama 30 menit P3: Kelompok pemaparan radiasi sinar UV C selama 60 menit P4: Kelompok pemaparan radiasi sinar UV C selama 120 menit dengan pembesaran $10 \times 10$

Hasil pengukuran diameter pulpa alba limpa (Tabel 1) terlihat bahwa kelompok kontrol memiliki diameter pulpa alba limpa terkecil yaitu380,24 $\pm 61,91 \mu \mathrm{m}$. Semakin lama perlakuan dengan pemaparan lampu UV C maka diameter pulpa alba limpa semakin meningkat pada pemaparan selama 15 menit memiliki diameter pulpa alba limpa 437,92 $\pm 95,59 \mu \mathrm{m}$, diameter pulpa alba limpa paling besar pada pemaparan selama $120(586,00 \pm 41,77 \mu \mathrm{m})$. Hasil uji Tukey menunjukkan perbedaa bermakna antar semua kelompok perlakukan kecuali pada kelompok kontrol dan kelompok perlakuan ultraviolet C selama 15 menit. Hal ini menunjukkan pemberian UV C selama 15 menit belum memberikan dampak pelebaran diameter pulpa alba limpa. Peningkatan diameter mulai didapatkan pada perlakukan selama 30 menit dan meningkat signifikan dengan peningkatan waktu pemaparan.

Tabel 1. Rata-rata diameter pulpa alba limpa mencit $(x \pm S D)$ dalam satuan $\mu \mathrm{m}$ pada kelompok kontrol dan perlakuan UV C

\begin{tabular}{ccc}
\hline No & Kelompok & Diameter Pulpa Alba Limpa $(\boldsymbol{\mu m})$ \\
\hline 1 & Kontrol & $380,24 \pm 61,91^{\mathrm{a}}$ \\
2 & Perlakuan UV 15' & $437,92 \pm 95,59^{\mathrm{a}}$ \\
3 & Perlakuan UV 30' & $480,48 \pm 167,55^{\mathrm{b}}$ \\
4 & Perlakuan UV 60' & $492,80 \pm 138,59^{\mathrm{c}}$ \\
5 & Perlakuan UV 120' & $586,00 \pm 41,77^{\mathrm{d}}$ \\
\hline
\end{tabular}

Keterangan: angka diameter pulpa alba limpa yang diikuti huruf yang sama berarti tidak ada beda nyata $(p<0,00)$
Hasil pengukuran indeks mitotik epidermis kulit mencit seperti terlihat pada Gambar 2. Hasil pengukuran indeks mitotik sel epidermis kulit mencit menunjukkan bahwa pada kelompok kontrol tanpa perlakuan apapun memiliki nilai indeks mitotik paling rendah yaitu 9,70 $\pm 2,27$ dibandingkan dengan semua kelompok perlakuan yang memilki nilai indeks mitotik lebih besar.

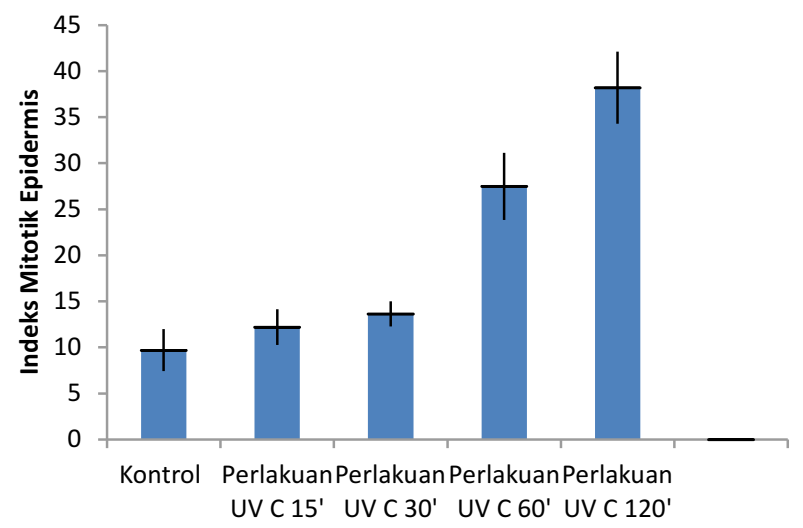

Gambar 2. Rata-rata indeks mitotik sel epidermis kulit mencit pada kelompok kontrol dan perlakuan dengan ultraviolet $\mathrm{C}$

Pada kelompok perlakuan terlihat bahwa semakin lama pemaparan sinar ultraviolet $\mathrm{C}$, maka semakin meningkat nilai indeks mitotik epidermis kulit mencit. Hasi uji one way ANOVA menunjukkan ada peningkatan bermakna indeks mitotik sel epidermis dengan semakin meningkatnya waktu pemaparan. Uji lanjut Tukey menunjukkan bahwa pada pemaparan selama 15 dan 30 menit belum menunjukkan perbedaan bermakna. Peningkatan bermakna indeks mitotik baru didapatkan pada pemaparan selama 60 menit dan 120 menit.

\section{DISKUSI}

Hasil pengukuran diameter pulpa alba limpa mencit setelah pemaparan sinar UV Cini menunjukkan bahwa telah terjadi proliferasi sel-sel limfosit pada pulpa alba limpa dalam menanggapi paparan sinar UV C. Paparan sinar UV C dengan intensitas rendah yaitu pemberian selama 15 menit secara statistik tidak bermakna dengan kelompok kontrol, tetapi pada paparan sinar ultraviolet $C$ selama 30 menit, 60 menit dan sampai dengan 120 menit, proliferasi limfosit semakin meningkat sehingga diameter pulpa alba limpa semakin membesar dan berbeda bermakna dengan kelompok kontrol. Hal ini menunjukkan bahwa pada pemaparan sinar UV C selama 30 menit sehari 2x selama 15 hari berturut-turut, sistem imun mulai terpicu untuk melakukan proliferasi dalam menanggapi paparan sinar UV C.

Paparan radiasi UV C mengakibatkan terjadinya pembesaran diameter pulpa alba limpa karena adanya aktivasi sistem imun sehingga terjadi proliferasi dari sel-sel pada pulpa alba limpa sebagai akibat respon adanya antigen asing yang masuk. Pada umumnya antigen asing masuk ke dalm tubuh melalui kulit, lapisan epitel gastrointestinal, dan sistem respirasi. Kulit, mukosa epitel, dan organ parenkim mengandung banyak pembuluh limfatik yang mempunyai saluran limfe mulai dari masuknya tempat antigen sampai ke limfonodus regional, di dalam lapisan epitel ini terdapat sel-sel dendritik yang akan mengikat antigen tersebut untuk dibawa ke kelenjar 
getah bening dan limfonodus regional lewat pembuluh limfatik tersebut agar diproses oleh limfosit $\mathrm{T}$, dan sebagian antigen yang tidak terikat oleh sel dendritik di lapisan epitel akan masuk ke dalam sistem sirkulasi dan aliran darah sehingga antigen tersebut akan di tangkap oleh Antigen Presenting Cell (APC) di dalam limpa untuk kemudian diproses oleh limfosit (10). Apabila kondisi ini terjadi secara berkelanjutan akan berakibat sistem imun tubuh tertekan dan terjadi mutasi DNA akibat pajanan sinar UV yang secara langsung dapat merusak DNA. Mutasi DNA akan berakibat sel-sel mengalami diferensiasi dari sel normal menjadi sel tumor. Perubahan ini tidak terjadi sekaligus, tetapi bersifat selektif, pertumbuhan meningkat berlebihan dan tidak terkendali sampai akhirnya terjadi perubahan menjadi kanker. Hal ini terjadi akibat pajanan sinar UV yang menimbulkan mutasi di gen TP53. Gen TP53 berfungsi sebagai anti proliferasi dan pengatur apoptosis sehingga apabila terjadi kerusakan di gen TP53 akan mengakibatkan sel-sel akan terus berproliferasi tetapi tidak mengalami apoptosis (11).

Radiasi UV B dan UV C dapat menekan sistem imun yaitu dengan menekan response cell mediated immune (CMI), penipisan sel epidermal langerhans, penekanan fungsi dari antigen presenting cell (APC) dalam reaksi konversi limfosit, penekanan fungsi dari natural killer cell (sel NK) dan penekanan contact hypersensitivity (CHS) dan delayed type hypersensitivity (DTH) (12). Radiasi UV C juga dapat merangsang respon perlindungan seluler yang mengarah pada kerusakan DNA dan kematian sel, tergantung pada intensitas paparan dan sensitifitas sel target (13).

Radiasi UV C pada sel-sel pulpa alba limpa mengakibatkan gangguan fungsi dari pulpa alba limpa yaitu sebagai tempat pematangan dan penggandaan limfosit serta menuntaskan diferensiasinya. Akibat gangguan fungsi tersebut, limfosit di tubuh akan mengalami peningkatan jumlah karena adanya respon imun, tetapi bila pemaparan radiasi UV C yang lama dan kronis akan berakibat terjadinya keganasan, dimana terjadi proliferasi dari sel-sel limfosit yang abnormal sehingga tidak dapat menjalankan fungsinya sebagai imunitas terhadap antigen atau benda asing yang masuk kedalam tubuh. Hal ini sesuai dengan penelitian yang menunjukkan bahwa paparan radiasi ultraviolet dapat menekan sistem imun (14). Pada penelitian tersebut didapatkan peningkatan kadar jumlah limfosit pada 30 hari penyinaran UV, hal ini menunjukkan bahwa terjadi respon imun terhadap antigen asing yang masuk yaitu radiasi sinar UV, sehingga pada gambaran histologi limpa terjadi pembesaran diameter pulpa alba. Pada penyinaran UV selama 60 hari juga didapatkan peningkatan jumlah limfosit dan bila penyinaran UV tersebut terus berlanjut akan berakibat terjadinya keganasan.

Penelitian yang dilakukan oleh Zaidah menyimpulkan bahwa paparan radiasi sinar UVB secara kronis mengakibatkan terjadinya perubahan patologis pada limpa mencit yang mengarah kepada terjadinya keganasan. Hal ini ditunjukkan dengan adanya nekrosis yang berat pada pulpa alba, infiltrasi sel-sel tumor ditemukannya megakariosit yang lebih dari normal pada satu lapang pandang (7). Penelitian lainnva dilakukan oleh

\section{DAFTAR PUSTAKA}

1. Halliday GM, Norval M, Byrne SN, Huang XX, and Wolf P. The Effect of Sunlight in Skin. Drug Discovery Today: Disease Mechanisms. 2008; 5(2): e201-e209.
Nurafriani. Dalam penelitian Nurafriani mencit yang diberi paparan radiasi elektromagnetik memberikan pengaruh pada sistem imun. Hal ini ditunjukkan dengan ukuran diameter pulpa alba limpa pada mencit yang diberi perlakuan tampak lebih besar bila dibandingkan dengan mencit kelompok kontrol (15). Hasil penelitian ini sesuai dengan penelitian Tasminatun dan Makiyah mengenai peningkatan indeks mitotik mencit yang diradiasi dengan sinar ultraviolet B (16). Demikian juga dengan hasil penelitian Adhiati yang menunjukkan bahwa pemaparan ultraviolet secara kronis menyebabkan kanker pada kulit berupa karsinoma sel skuamosa pada aurikula mencit (17).

Hasil pengukuran indeks mitotik epidermis kulit mencit setelah pemaparan sinar UV C ini menunjukkan bahwa telah terjadi proliferasi sel-sel pada stratum basale epidermis kulit mencit dalam menanggapi paparan sinar UV C. Indeks mitotik epidermis kulit mencit pada paparan sinar UV C selama 15 menit dan 30 menit tidak berbeda bermakna, selanjutnya pada paparan sinar ultraviolet $C$ selama 30 menit, 60 menit dan sampai dengan 120 menit, indeks mitotik epidermis kulit semakin meningkat dan berbeda bermakna dengan kelompok kontrol. Hal ini menunjukkan bahwa pada pemaparan sinar UV C selama 15 menit sehari $2 x$ selama 15 hari berturut-turut, sel-sel stratum basale epidermis kulit mulai terpicu untuk melakukan proliferasi dalam menanggapi paparan sinar UVC.

Pada saat kulit terpapar oleh sinar UV C, maka lapisan zat tanduk terluar akan mengalami kerusakan, sebagai responnya sejumlah sel pada lapisan basal akan meningkatkan respon dengan hiperplasi melalui proses mitosis, sehingga sel-sel pada lapisan terluar akan meningkatkan proses keratinisasi untuk merespon paparan sinar UV C sekaligus sebagai proses perbaikan kulit. Apabila paparan sinar UV C terjadi berulang kali, maka respon kulit juga akan semakin meningkat dengan penebalan zat tanduk dan hiperplasi pada stratum basal epidermis kulit. Respon ini sangat berguna sebagai pelindung epidermis dari rangsangan eksternal yang sifatnya membahayakan.

Hal ini disebabkan oleh karena sinar ultraviolet mampu meningkatkan proses mitosis pada lapisan epidermis kulit sehingga menyebabkan lapisan epidermis mengalami peningkatan ketebalan. Menurut Djuanda adanya stimulus sinar UV C menyebabkan lapisan epidermis mengalami peningkatan ketebalan oleh karena hiperkeratinisasi. Hiperkeratinisasi merupakan proses perubahan selular pada sel epidermis. Lapisan epidermis memiliki 3 jenis sel utama yaitu keratinosit, sel Langerhans dan melanosit. Keratinosit dimulai dari stratum basale mengadakan pembelahan, sel basal yang lain akan berpindah ke atas dan berubah bentuknya menjadi sel spinosum, makin ke atas sel menjadi makin gepeng dan bergranula menjadi sel tanduk yang amorf. Proses ini berlangsung terus menerus seumur hidup (18). Hasil penelitian menunjukkan semakin lama pemaparan lampu ultraviolet $\mathrm{C}$, maka terjadi peningkatan diameter pulpa alba limpa dan semakin besar aktivitas proliferasi sel epidermis kulit mencit ditunjukkan dengan peningkatan indeks mitotik sel epidermis kulit mencit.
2. Mac Kie RM. Long Term Health Risk to the Skin of Ultraviolet Radiation. Progress in Biophysics and Molecular Biology. 2006; 92(1): 92-96.

3. Matsumura Y and Ananthaswamy HN. Toxic Effect of 
Ultraviolet Radiation on Skin. Toxicology and Applied Pharmacology. 2004; 195(3): 298-308.

4. Gallagher RP and Lee TK. Adverse Effect of Ultraviolet Radiation: A Brief Review. Progress in Biophysics and Molecular Biology. 2006; 92(1): 119-131.

5. Young AR. Acute Effects of UVR on Human Eyes and Skin. Progress in Biophysics and Molecular Biology. 2006; 92(1): 80-85.

6. Junqueira LC dan Carniero J. Histologi Dasar: Teks \& Atlas. 10th edition. Jakarta: EGC; 2007; hal. 251-276.

7. Zaidah N. Gambaran Histologi Limpa Mencit (Mus musculus) setelah Pemaparan Sinar Ultraviolet secara Kronis. [Skripsi]. Universitas Muhammadiyah, Yogyakarta. 2007.

8. Trevisan A, Piovesan S, Leonardi A, et al. Unusual High Exposure to Ultraviolet-C Radiation. Photochemistry and Photobiology. 2006; 82(4): 1077-1079.

9. Dahlan MS. Statistika untuk Kedokteran dan Kesehatan. Jakarta: Arkans; 2007; hal. 65-87.

10. Baratawidjaja KG. Imunologi Dasar. 7th edition. Jakarta: Balai Penerbit FK UI; 2006; hal. 6-33.

11. Asrouddin, Huriawati $\mathrm{H}$, dan Nurwany D. Buku Ajar Patologi. 7th Edition. Jakarta: EGC; 2007; hal. 185237.
12. Gill EM and Kim TH. UV-Induced Immune Suppression and Sunscreen. Photodermatol Photoimmunol \& Photomedicine. 2000; 16: 101-110.

13. Kumar, V, Abbas, and Fausto. Robbins and Cotran Pathologic Basic of Disease. 7th edition. Philadelphia, Pennsylvania: Elsevier Saunders; 2005: hal. 441-442.

14. Cetin E and AltinsaatC. Effects of Ultraviolet Radiation on Some Immunological Parameters in Rats. American-Eurasian Journal of Agricultural \& Environmental Sciences. 2006; 1(1): 31-36.

15. Nurafriani I. Pengaruh Pajanan Radiasi Elektromagnetik terhadap Struktur Histologi Limpa pada Mencit (Mus musculus). [Skripsi]. Universitas Muhammadiyah, Yogyakarta. 2007.

16. Tasminatun S dan Makiyah SNN. Efek Kemopreventif Ekstrak Etanolik Biji Jinten Hitam (Nigela Sativa) pada Terjadinya Kanker Kulit Terinduksi Ultraviolet. [Laporan Penelitian Hibah A2]. Universitas Muhammadiyah, Yogyakarta. 2007.

17. Adhiati F. Efek Pemaparan Ultraviolet secara Kronis terhadap Histologi Auricula Mencit. [Skripsi]. Universitas Muhammadiyah, Yogyakarta. 2007.

18. Djuanda A. Ilmu Penyakit Kulit dan Kelamin. Edisi 3. Jakarta: Balai Penerbit Fakultas Kedokteran Universitas Indonesia; 2005. 